\title{
Genetic evaluation for TOR1-A (DYT1) in Brazilian patients with dystonia
}

\author{
Avaliação genética para TOR1-A (DYT1) em pacientes brasileiros com distonia \\ Carlos Henrique F. Camargo ${ }^{1,2}$, Sarah Teixeira Camargos ${ }^{3}$, Salmo Raskin ${ }^{4,5}$, Francisco Eduardo C. Cardoso ${ }^{3}$, \\ Hélio Afonso G. Teive ${ }^{1}$
}

\begin{abstract}
Several genes have been mapped in families or in sporadic cases of dystonia. TOR1-A (DYT1) gene was linked to isolated dystonia. Objective: To associate clinical information of patients with dystonia with the TOR1-A gene mutations. Method: Eighty-eight patients with dystonia in cervical area (focal, segmental, multifocal and generalized) were recruited at Movement Disorders Clinic of Hospital de Clínicas of the Federal University of Paraná between June of 2008 and June of 2009. They were submitted to the clinical evaluation. DNA was extract from blood and submitted at analysis to TOR1-A mutations by PCR according standard protocols. Results: Two patients had c.907GAGdel mutation on TOR1-A gene. These patients, with familial history of dystonia, started his symptoms by legs and had secondary generalization. Conclusion: We can suggest that analysis for TOR1-A mutations should be performed only in patients with early onset, generalized and familial dystonia.
\end{abstract}

Keywords: dystonia, cervical dystonia, DYT1, genetic.

\section{RESUMO}

Tem sido mapeada uma série de genes em pacientes com distonia. 0 gene TOR1-A (DYT1) foi associado a casos de distonia primária. Objetivo: Associar os achados clínicos dos pacientes com distonia com mutações em TOR1-A. Método: Foram selecionados 88 pacientes com distonia na região cervical (focal, segmentar, multifocal e generalizada) no Setor de Distúrbios do Movimento do Hospital de Clínicas da Universidade Federal do Paraná entre junho de 2008 e junho de 2009. Esses pacientes foram submetidos à avaliação clínica. O DNA foi extraído do sangue periférico e submetido à análise para mutações em TOR1-A através de protocolos padronizados. Resultados: A mutação c.907GAGdel foi encontrada em duas pacientes. Ambas tinham história familiar de distonia e iniciaram seus sintomas pelos membros inferiores, evoluindo com generalização. Conclusão: Podemos sugerir que a análise para mutações em TOR1-A deve ser realizada em pacientes com distonia de inicio precoce, história familiar e generalização.

Palavras-chave: distonia, distonia cervical, DYT1, genética.

The definition of dystonia was recently revisited. Currently, dystonia is a movement disorder characterized by sustained or intermittent muscle contractions causing abnormal, often repetitive, movements, postures, or both. Dystonic movements are typically patterned, twisting, and may be tremulous. Dystonia is often initiated or worsened by voluntary action and associated with overflow muscle activation $^{1}$. Most of voluntary muscles can be affected. The most common form of dystonia is that affect the musculature of the neck (cervical dystonia), in a focal way or associated to other parts of the body ${ }^{2}$.
Over the past 20 years, several loci (from DYT1 to DYT25) have been mapped in families with pure forms of dystonia, dystonia plus other movement disorders, or in sporadic cases $^{3}$. TOR1- $A$ (DYT1) was the first gene linked to primary dystonia. TOR1- $A$ is transmitted in an autosomal dominant fashion with penetrance ranging from 30 to $40 \%$ and the onset of clinical features commonly occurs during childhood or adolescence ${ }^{4}$.

A 3-base pair (GAG) deletion in the coding region of the TOR1-A gene, located at chromosome 9q34, causes the expression of an abnormal protein named torsinA, a protein

${ }^{1}$ Serviço de Neurologia, Hospital de Clínicas, Universidade Federal do Paraná, Curitiba PR, Brazil;

${ }^{2}$ Serviço de Neurologia, Hospital Universitário, Universidade Estadual de Ponta Grossa, Ponta Grossa PR, Brazil;

${ }^{3}$ Serviço de Neurologia, Hospital das Clínicas, Universidade Federal de Minas Gerais, Belo Horizonte MG, Brazil;

${ }^{4}$ Laboratório Genetika, Curitiba PR, Brazil;

${ }^{5}$ Pontifícia Universidade Católica do Paraná, Curitiba PR, Brazil.

Correspondence: Carlos Henrique Ferreira Camargo; Serviço de Neurologia, Hospital de Clínicas, Universidade Federal do Paraná; Rua General Carneiro, 181; 80060-900 Curitiba PR, Brasil; E-mail: chcamargo@uol.com.br

Conflict of interest: There is no conflict of interest to declare.

Received 08 December 2014; Received in final form 28 June 2014; Accepted 18 July 2014. 
belonging to the AAA+ chaperone family ${ }^{4}$. Patients with TOR1$A$ mutations (delE302/303) usually have the onset in a limb with rapid spread to generalized dystonia, with cranio-cervical sparing ${ }^{4,5,6,7}$. However, the spectrum of dystonia produced by the TOR1-A GAG deletion is broad and severity may vary in patients even within siblings. To correlate the phenotype of TOR1-A gene mutations in patients with dystonia, we performed a sequencing analysis of this gene in a cohort of patients in a Brazilian center of movement disorders.

\section{METHOD}

The study was approved by the local ethics committee CEP-UFPR ethical approval 1676.093/2008-06) and recruited patients provided signed informed consent.

\section{Subjects Selection and Clinical Assessment}

A total of 88 patients ( 56 female) with dystonia with cervical involvement who attended the Botulinum Toxin and Movement Disorders Outpatient Unit in the Neurology Service, Hospital de Clínicas, Universidade Federal do Paraná, from June 2008 to June 2009, were selected for the study. Two movement disorders specialists examined all patients (C.H.C and H.A.T). Patients were submitted to brain computed tomography (CT scan) and cervical-spine radiography. Additional tests included complete blood count (CBC), TSH, VDRL, blood glucose test, ESR, electrolyte levels and liver and kidney function. Cervical spine CT scan and magnetic resonance imaging (MRI) and brain MRI as well as other laboratory tests were requested according to the clinical assessment of each patient. We selected all dystonic patients (focal, segmental, multifocal or generalized) without etiological diagnosis.

\section{Mutation scanning of TOR1-A gene}

DNA was extracted from peripheral blood leukocytes. Amplifications were performed using GoTaq ${ }^{\circledR}$ Colorless Master Mix (Promega, Madison, WI) in a final volume of $25 \mu \mathrm{l}$ containing $100 \mathrm{ng}$ of genomic DNA and $10 \mathrm{pmol}$ of each primer. Primers and conditions were performed as previously described followed by sequencing ${ }^{4}$.

\section{RESULTS}

There were 16 families with $23(26.74 \%)$ patients. Technical problems did not allow the genetic analysis in 6 patients (one familial and 5 sporadic cases). Thus, the sequencing analysis of TOR1-A mutations was done in 82 (93.2\%) patients.

Among the 88 patients, 36 (40.91\%) had focal cervical dystonia. Other $22(25 \%)$ patients had segmental dystonia (6 with cranial-cervical dystonia, 13 with arms-cervical dystonia, 3 with arm-cranial-cervical dystonia, and one with laryngeal-cranial-cervical dystonia). Two (2.28\%) patients with multifocal dystonia had abnormal movement in left leg. A generalized dystonia was observed in 28 (31.81\%) patients.

The mean age at onset of the group was $30.47 \pm 21.16$ years old (range, 5 months to 72 years old). The mean age at onset of focal dystonia (41.05 \pm 16.87$)$, and segmental dystonia patients (35.55 \pm 24.13$)$, was higher than the generalized dystonia group, $12.36 \pm 9.10(\mathrm{p}<0.001)$. Three patients, one with generalized and two with segmental dystonia presented Parkinsonism. The patients with segmental dystonia were familial cases and started the features at 64 and 70 years old. The sporadic case started the symptoms at 17 years old by neck area with generalization in two years. No levodopa response was observed in these patients. Other four patients, two with segmental and two with generalized dystonia, had myoclonus. The mean age of onset was $15.5 \pm 5.07$ (range, 12 to 23 years), without familial history or other movement disorders.

Two patients, from two different families (Figure 1) presented the 3-bp (GAG deletion) at the exon 5 of TOR1-A gene (Figure 2). Both were familial and generalized cases with onset in the legs at 7 and 12 years old respectively (Table). The relatives did not accept the invitation to clinical examination and blood sample collect to analysis.

No patient with mutations for TOR1-A gene had other movement disorders (myoclonus or Parkinsonism).

\section{DISCUSSION}

Currently, despite of the identification of several loci related with dystonia, the TOR1-A (DYT1), THAP-1 (DYT6), CIZ1 (DYT23), ANO-3 (DYT24) and GNAL (DYT25) genes are the only linked to isolated ("primary") dystonias ${ }^{3,4}$. The analysis of the TOR1-A (DYT1) was the aim of this research. We found an in-frame 3-bp deletion (GAG deletion), in TORI-A gene, in two familial patients. To date, a GAG deletion in exon 5 of TOR1-A was related with almost all cases of DYT1 dystonia ${ }^{3,4,5}$.

Our two patients with TOR1-A mutation presented typical DYT1 clinical features, with onset of symptoms by legs spraying to generalization, except for cervical involvement. Both had predictive factors to DYT1 dystonia According to a Task Force of European Section of Movement Disorders Society and the European Federation of Neurological Societies, (1) patients with limb-onset, (2) isolated dystonia with onset before age of 30 , and (3) those with onset after age of 30 if they have an affected relative with early-onset dystonia age of onset before 30 years old ${ }^{8}$. About $60 \%$ of the patients with TOR1-A mutation present a "typical" phenotype with a generalized, early-onset dystonia beginning in arms or mainly in legs, 


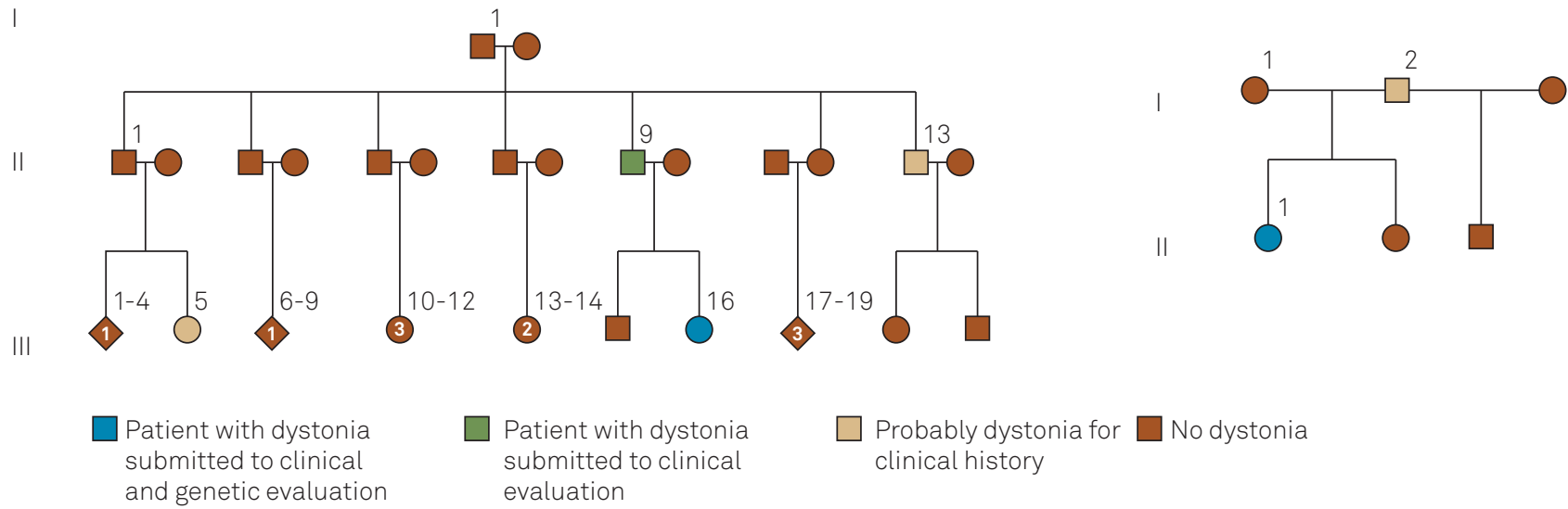

Family 1, patient A (Right). Family 2, patient B (Left)

Figure 1. Familial pedigrees of patients with TOR1-A gene mutations.

and without involvement of cranial or neck muscles. The majority of the patients DYT1 present generalization, caudal to rostral, in a time frame of 5 years. However, cranialcervical involvement has also been described as part of exceptional phenotypes of DYT1 dystonia, even focal or segmental disease $e^{5,6,7,8}$.

We did not find DYT1 cases started by neck or staying in focal or segmental types. All the patients with cranialcervical dystonia analyzed by Valente et al. ${ }^{5}$ were negative for GAG deletion on TOR1-A gene. Among focal dystonia patients, $98 \%$ did not present the mutation for TOR1-A gene. Restrict forms are exceptional presentations, they can occur in $21 \%$ of the DYT1 patients, however, these patients ordinarily have a familial history ${ }^{6,9}$. This phenotype variability in the same family can occur, even mild focal form or severe generalized dystonia9. Asymptomatic cases also can occur in DYT1 families ${ }^{5}$. Because the variable expression and low penetrance of the gene $(30-40 \%)$, additional genetic factors

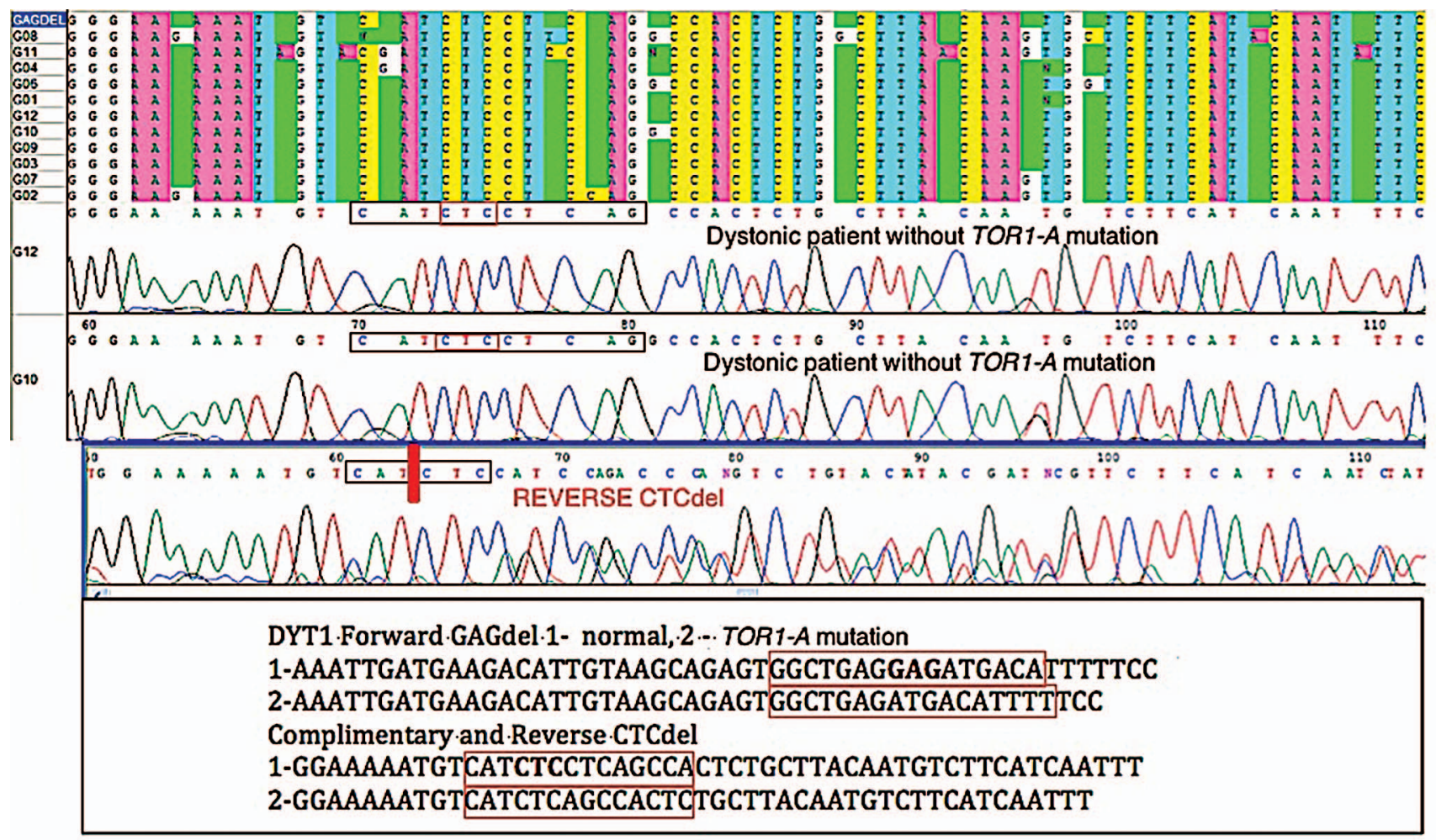

Figure 2. TOR1-A mutation in a patient with generalized dystonia. 
Table. Clinical features of patients with TOR1-A mutation.

\begin{tabular}{|c|c|c|c|c|c|c|}
\hline Patient/Family & Sex & Type of dystonia & $\begin{array}{l}\text { Age of onset } \\
\text { (years) }\end{array}$ & $\begin{array}{c}\text { Evolution } \\
\text { (years) }\end{array}$ & $\begin{array}{l}\text { Site of } \\
\text { onset }\end{array}$ & Familial history \\
\hline A Family 1 III-16 & $F$ & $\begin{array}{c}\text { Generalized } \\
\text { (trunk, arms, legs and neck) }\end{array}$ & 7 & 6 & Legs & $\begin{array}{l}\text { Father started features } \\
\text { at } 12 \text { years old, currently, } \\
\text { generalized dystonia. } \\
\text { One uncle and one cousin } \\
\text { with generalized dystonia }\end{array}$ \\
\hline B Family 2 II-1 & $F$ & $\begin{array}{c}\text { Generalized } \\
\text { (trunk, arms, legs and neck) }\end{array}$ & 33 & 12 & Legs & Father with cervical dystonia \\
\hline
\end{tabular}

and environment factors can contribute to manifestation to the disease and to severity of symptoms ${ }^{6,10}$.

Despite the variability of the phenotype, two clinical findings remain with certain consistency, (1) onset of symptoms before 20 years old, and (2) onset of symptoms by limbs ${ }^{11}$. Based on this principle, the recommendations for clinical analysis to DYT1 have been modified. These analyses should be made to patients who started the case by a limb before 26 years. Thus, routine testing for DYT1 dystonia in patients with focal dystonia started after 26 years old sounds unwarrantable ${ }^{11}$.

In conclusion, we can suggest that analysis for TOR1- $A$ mutations should be performed only in patients with early onset, generalized, and familial dystonia.

\section{REFERENCES}

1. Albanese A, Bhatia K, Bressman SB, Delong MR, Fahn S, Fung VS et al. Phenomenology and classification of dystonia: a consensus update. Mov Disord. 2013;28(7):863-73. http://dx.doi.org/10.1002/mds.25475

2. Tsui JK. Cervical dystonia. In: Tsui JK, Calne D, editors. Handbook of distonia. New York: Marcel Dekker; 1995. p. 115-27.

3. Lohmann K, Klein C. Genetics of dystonia: what's known? What's new? What's next? Mov Disord. 2013;28(7):899-905. http://dx.doi.org/ $10.1002 /$ mds. 25536

4. Ozelius LJ, Hewett JW, Page CE, Bressman SB, Kramer PL, Shalish C et al. The early-onset torsion dystonia gene (DYT1) encodes an ATPbinding protein. Nat Genet. 1997;17(1):40-8. http://dx.doi.org/10.1038/ ng0997-40

5. Valente EM, Warner TT, Jarman PR, Mathen D, Fletcher NA, Marsden CD et al. The role of DYT1 in primary torsion dystonia in Europe. Brain. 1998;121(12):2335-9. http://dx.doi.org/10.1093/brain/121.12.2335

6. Bressman SB, Sabatti C, Raymond D, Leon D, Klein C, Kramer PL et al. The DYT1 phenotype and guidelines for diagnostic testing. Neurology. 2000;54(9):1746-52.
O'Riordan S, Raymond D, Lynch T, Saunders-Pullman R, Bressman $\mathrm{SB}$, Daly $\mathrm{H}$ et al. Age at onset as a factor in determining the phenotype of primary torsion dystonia. Neurology. 2004;63(8):1423-6.

8. Albanese A, Barnes MP, Bhatia KP, et al. A systematic review on the diagnosis and treatment of primary (idiopathic) dystonia and dystonia plus syndromes: report of an EFNS/MDS-ES Task Force. Eur J Neurol. 2006;13(5):433-44. http://dx.doi.org/10.1111/j.1468-1331.2006.01537.x

9. Gambarin M, Valente EM, Liberini P, Barrano G, Bonizzato A, Pandovani A et al. Atypical phenotypes and clinical variability in a large Italian family with DYT1-primary torsion dystonia. Mov Disord. 2006;21(10):1782-4. http://dx.doi.org/10.1002/mds.21056

10. Edwards M, Wood N, Bhatia K. Unusual phenotypes in DYT1 dystonia: a report of five cases and a review of the literature. Mov Disord. 2003;18(6):706-11. http://dx.doi.org/10.1002/mds.10411

11. Gajos A, Piaskowski S, Sławek J, Ochudlo s, Opala G, èobińska A et al. Phenotype of the DYT1 mutation in the TOR1-A gene in a Polish population of patients with dystonia: a preliminary report. Neurol Neurochir Pol. 2007;41(5):487-94. 